ENCYCLOPEEDIE Encyclopédie berbère

BERBERE

$4 \mid 1986$

4 | Alger - Amzwar

\title{
Amastan / MSTN
}

\section{S. Chaker}

\section{OpenEdition}

Journals

Édition électronique

URL : http://journals.openedition.org/encyclopedieberbere/2463

DOI : $10.4000 /$ encyclopedieberbere.2463

ISSN : 2262-7197

\section{Éditeur}

Peeters Publishers

\section{Édition imprimée}

Date de publication : 1 septembre 1986

Pagination : 561

ISBN : 2-85744-282-3

ISSN : 1015-7344

\section{Référence électronique}

S. Chaker, «Amastan / MSTN », Encyclopédie berbère [En ligne], 4| 1986, document A181, mis en ligne le 01 décembre 2012, consulté le 12 octobre 2020. URL : http://journals.openedition.org/ encyclopedieberbere/2463; DOI : https://doi.org/10.4000/encyclopedieberbere.2463

Ce document a été généré automatiquement le 12 octobre 2020

(c) Tous droits réservés 


\section{Amastan / MSTN}

\section{S. Chaker}

1 Anthroponyme libyque et touareg. C'est l'un des rares prénoms berbères qui soient attestés depuis l'Antiquité jusqu'à la période actuelle.

$2-M S T N$ (libyque) : représenté dans les noms (composés de deux éléments) des princes M S T N - B (Mastanabal) et M S T N - Z N (Mastanesosus).

- Amāstan (touareg): nom commun et prénom (célèbre par Mūsa ag Amāstan, amenukal de l'Ahaggar au début du siècle).

3 Touareg Ahaggar : amāstan, « défenseur, protecteur ». Ce nom est issu d'un verbe :

- Ahaggar: mesten = "protéger, garantir, défendre, se disputer» (Foucauld, III, pp. 1257-58);

- T. méridionale : măstăn = « discuter, argumenter, défendre (en paroles) » (Alo-jaly, p. 180).

4 Le verbe mesten est lui-même un dérivé à nasale (à valeur réciproque) d'un verbe tombé en désuétude : esten, « répondre à » (Alojaly, p. 180). Le dérivé à sifflante («factitif»), sesten, « interroger, poser une question » (« faire répondre quelqu'un ») est en revanche bien vivant en touareg et hors de ce domaine, au Mzab notamment (cf. Delheure, 1984, p. 194).

5 La signification première de mesten est donc « se répondre l'un à l'autre, argumenter, se faire face (en paroles), s'affronter verbalement». Et Amāstan signifie fondamentalement : « le défenseur (en paroles), l'avocat ». Ce dernier sens est d'ailleurs celui qui lui été attribué dans la néologie kabyle actuelle (cf. Amawal). 


\section{BIBLIOGRAPHIE}

ALOJALY Gh., Lexique touareg-français, Copenhague, 1980.

Amawal, (Lexique), Paris, Imedyazen, 1980 (glossaire néologique).

CHAKER S., « Onomastique berbère ancienne (Antiquité/Moyen Age) : rupture et continuité », BCTH, n.s., 1, 1983 (1985), pp. 483-497, repris dans : Textes en linguistique berbère..., Paris, C.N.R.S., 1984.

DELHEURE J., Dictionnaire mozabite-français, Paris, SELAF, 1984.

FOUCAULD Ch. de, Dictionnaire touareg-français, Paris, 1951-52.

INDEX

Mots-clés : Libyque (langue et écriture), Onomastique 